\title{
Groundwater vulnerability assessment in coastal plain of Rio Grande do Sul State, Brazil, using drastic and adsorption capacity of soils
}

\author{
Ronaldo Herlinger Jr · Antonio Pedro Viero
}

Published online: 6 May 2008

(C) Springer-Verlag 2008

Erratum to: Environ Geol (2007) 52:819-829

DOI 10.1007/s00254-006-0518-4

Unfortunately, the following errors occurred:

In the Adsorption Capacity of Soils item, and Tables 9 and 10 , the correct unit is $\mathrm{mmol} / \mathrm{kg}$ and not $\mathrm{mmol} / \mathrm{g}$.

The online version of the original article can be found under doi:10.1007/s00254-006-0518-4.

R. Herlinger Jr $(\bowtie) \cdot$ A. P. Viero

Instituto de Geociências,

Universidade Federal do Rio Grande do Sul,

Caixa Postal 15.001, CEP 91501-970 Porto Alegre, RS, Brasil

e-mail: 00105509@ufrgs.br

A. P. Viero

e-mail: pedro.viero@ufrgs.br 